\title{
Identification of Condition in Coastal Metinaro Mangrove Forest, Timor-Leste
}

\author{
Luis da Costa \\ Environmental Science \\ Sebelas Maret University \\ Solo City, Indonesia \\ MTh. Sri Budiastuti \\ Environmental Science \\ Sebelas Maret University \\ Solo City, Indonesia \\ Sunarto \\ Environmental Science \\ Sebelas Maret University \\ Solo City, Indonesia \\ Joko Sutrisno \\ Environmental Science \\ Sebelas Maret University \\ Solo City, Indonesia
}

Corresponding email: luisdacostauntl@yahoo.com

\begin{abstract}
The mangrove ecosystem is one special and unique form of forest ecosystems with potential beach resources. However, the condition of the forest is generally under a high pressure of economic crisis, limited job vacancies and lack of awareness of the coastal community. This study was aimed at identifying the condition of the mangrove forest in Metinaro coastal at present and assessing the level of damage. This study was a descriptive qualitative research using a survey visual photographs and site map. The results showed that the condition of the mangrove forest in Metinaro beach at present falls into the damaged category caused by two aspects: anthropogenic and natural causes. The anthropogenic damage is caused by human beings, such as the opening of mangrove land and converting it into fish, shrimp, and crab ponds, source of firewoods, and building materials, while the natural damage is caused by storm, wave, sea wind, and the age of the plants, as well as damages caused by domestic animals. The impacts take the form of abrasion and the thinning of the mangrove forest so that the biodiversity becomes less and less and there is a decrease in the income of the fishermen. Thus, the first priority in correcting the damage and in rehabilitating the mangrove in Metinaro beach need to be done by developing cooperation with the government and the community in implementing mangrove program replantation. Considering that anthropogenesis plays a part as the main cause of the thinning of the thickness and damage of the mangrove.
\end{abstract}

Keywords-Mangrove forest, anthropogenic, nature

\section{INTRODUCTION}

Mangrove forest is one unique and special form of forest ecosystems and forms the most potential natural resource, the condition of the mangrove forest in Metinaro, in general, undergoes a high pressure caused by the economic crisis so that the mangroves are being felled and a conversion has occurred, some areas in Timor-Leste have been damaged. Mangrove forest is the last bastion that protects the residential area and other land environments from various natural disasters such as abrasion, storm attacks, tsunami waves, strong winds, and seawater intrusion (Onrizal, 2003).

The mangrove forest ecosystem is generally found in coastal areas that are the meeting places between land and sea, and the mangrove forest is a complex and unique ecosystem and has a great holding capacity for the surrounding water area environments. Mangrove forest is one of the ecosystems in the coastal area with a high potential for the welfare of the community economically, socially as well as environmentally. While Noor, et al ( 2006) state that mangrove can also be used for commercial purposes such as for exported woods, barks for tanning, charcoal, material for paper, medicine, and food.

Based on the observation of the use of land it is known that the mangrove forest vanished because of being converted into ponds (shrimp, crab, and parrot fish ponds) that become the flagship products of the Metinaro community. According to Suyadi (2009), one of the products that have the highest economic value forms the mangrove ecosystem is coastal fish. 
The increasing economic demand of the coastal community and the rapid physical development in Metinaro region caused the increasingly degraded mangrove condition. This is clear when one compares the total area of the mangrove forest ecosystem in Metinaro before the damage (425,6 ha) and the total area of the mangrove forest left $(320,06 \mathrm{ha})$, thus the Metinaro area that has undergone the ecosystem loss is 105,54 ha.

In the light of the functions and the roles of the mangrove forest ecosystem in supplying the increasing economic needs of the community, the people have to manage the mangrove ecosystem well. The information about the identification and the level of damage of the mangrove ecosystem is very important to formulate new policies on the management of the coastal area especially the mangrove ecosystem. On the basis of the above description, then a study was conducted on the identification of the condition of the mangrove ecosystem in Metinaro beach, Timor-Leste. The aim of this study was to identify the condition of the mangrove ecosystem in Metinaro at present and to assess the level of damage of the mangrove forest. This is very important to be done.

\section{METHOD}

\section{A. Time and Place of Research}

- Place of Research

This research was done in Metinaro District, TimorLeste.

- Time of Research

This research was done on the first of December 2014 the first of January 2015.

\section{B. Equipment and Materials}

- The equipment used in this study were the map of damaged locations, the string of raffia, a cleaver, a writing pad, a ballpoint, and wooden pegs.

- Materials: Mangrove forest

\section{Population and Sample}

- Population; In qualitative research, the relation between population and sample is very close, since: the population is the whole objects that are studied (Suyanto and Sutinah, 2005). Thus, the population in this study was all mangrove forest ecosystem in Metinaro, Timor-Leste.

- Sample; Some of mangroves in Metinaro at present are undergoing damages and were used as the sample in this study.

\section{Type and source of data}

The data in this research were differentiated based on two types of data, i.e. :
- Primary Data; the primary data were obtained through a survey method, field observation, while secondary data; the secondary data came from the village office and offices that are related to the map of mangrove condition

- Primary data source; the primary data were obtained directly from the location of research through a survey and direct recording in the location of research, while secondary data source; secondary data were obtained from the village Office and other related offices.

\section{E. Technique of data collection about the condition of the mangrove forest at present}

The research used purposive sampling to collect data for selecting a sample in the location of research based on various considerations. According to Sugiyono (2010), purposive sampling is a technique of sampling from its source based on certain consideration. The researcher considered in this research the way of finding and selecting a location of sampling of the real condition of the mangrove forest and this location would be assigned as a place for sampling that he believed would facilitate him in obtaining the data expected.

\section{F. Data Analysis}

The research used the descriptive qualitative technique to analyze the data in this research, by giving an account about the real condition of the mangrove forest in Metinaro at present as proven by photographs of the real condition and a map of the location of research.

\section{FINDING AND DISCUSSION}

\section{A. Condition of the area of research}

Geographically Timor-Leste lies between $8^{\circ} 31^{\prime} 46^{\prime \prime} S$ Latitude- $125^{\circ} 44^{\prime} 10^{\prime \prime}$ E Longitude with the area of $\pm 14,874$ sq.km occupied by about $1.060,880$ people. Sub-district Metinaro including administrative region of Dili district, and province Dili with boundaries among others:

- To the North, it is bounded by the sea

- To the South, it is bounded by Remexio Sub-District, Aileu District.

- To the East, it is bounded by Uma Kaduak Village, Laclubar Sub-District.

- To the West, it is bounded by Hera Village, Beraka Habitation. The entire area is 91,24 sq.km

Predetermined observation points in particular (mangrove adults and puppies) with global position system (GPS) location research, and then by using Google Earth satellite images in 2013 version 10.1 to distinguish the mature mangrove and mangrove saplings. It is the same as in the 2005 study, which can be seen in Figure 1. 


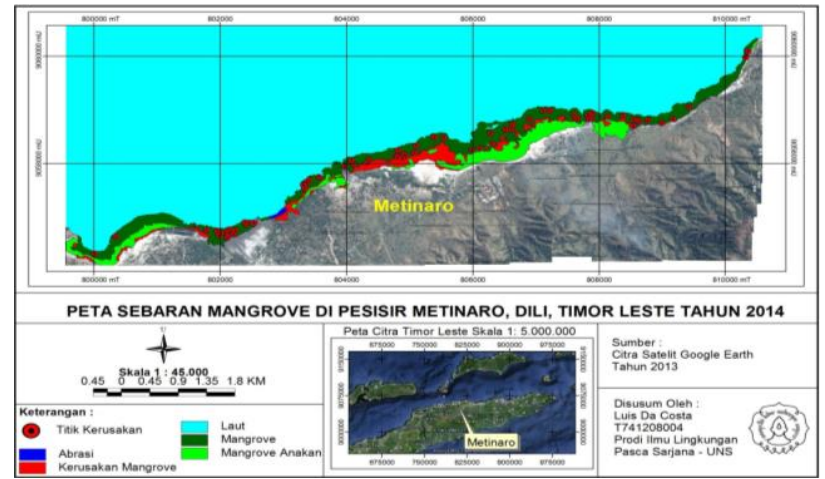

Fig. 1. Map of the location of research and damage of the mangrove forest in Metinaro

Timor-Leste has a dry tropical climate that is very varied geographically and is influenced very much by seasons (Trainor, et al., 2007). Furthermore, in North Coast, the rainy season just lasts for 4-6 months starting from west monsoon wind in November and December (the rainfall $<1.000 \mathrm{~mm}$ a year), with towns such as Manatuto and Vemasi that are the driest towns in South East Asia.

According to Trainor, et al., (2007), there are two peaks of rainy season in the south coast: in December and in April-June with the total number of wet months $=7-9$ months (the rainfall $>2,000 \mathrm{~mm}$ a year) while the region in the central part that is mountainous and Fuiloro high land around Lospalos is also a wet area (the rainfall $>2000 \mathrm{~mm}$ a year) with the peak between May and June. Meanwhile, it is also known that not only there the rain and dry season in Timor-Leste from July and November but the humidity is also low. The temperature in Timor-Leste during the day time falls about $4-5^{\circ} \mathrm{C}$ in every addition of height of $1,000 \mathrm{~mm}$, such as in Maubisse that lies in $1,400 \mathrm{~m}$ from the sea level that has a cool weather with the temperature in the day time between $23-28^{\circ} \mathrm{C}$ (the temperature in the night is $10-20^{\circ} \mathrm{C}$ ). In Timor-Leste, in lowlands such as in Dili, Metinaro, Kasait, Area Branca and Tibar it is usually hot in the day time $\left(31-33^{\circ} \mathrm{C}\right)$ and warm $\left.20-25^{\circ} \mathrm{C}\right)$ in the night. According to Trainor, et al., (2007), the lowland and seaside towns such as Dili is usually hot in the day time $\left(1-33^{\circ} \mathrm{C}\right)$ and warm $\left(20-25^{\circ} \mathrm{C}\right)$ in the night.

\section{B. Area of mangrove forest ecosystem on Metinaro beach}

Metinaro is surrounded by hills (closed) that can protect the land from wave attacks so that the mangrove forest ecosystem in Metinaro beach is the largest in Timor-Leste, this is supported by a sloppy topography in the form of clay overlay that is appropriate for the mangrove forest growth. The characteristic of such beach actually is very good for the growth and development of mangrove forests. The result of this research shows that the area of the mangrove forest in Metinaro beach has become narrower and narrower and, in general, the condition of the ecosystem of mangrove forest at present causes it to become an object of much concern; for example, the mangrove forest in the central part of Metinaro region becomes thinner and thinner so that the thickness is 10 $\mathrm{m}$ and the mangrove forest in other parts still has a thickness of more than $300 \mathrm{~m}$ from the coastal line and is old that causes a hindrance to the growth of mangroves. This can be seen in Table 1.

TABLE 1. THE LEVEL OF DESTRUCTION OF MANGROVE FOREST IN THE CORENT METINARO

\begin{tabular}{|c|c|c|c|}
\hline Mangrove condition & 2005 & 2014 & Total of damages \\
\hline Mangrove forest & 425,6 ha & 320,06 ha & 105,54 ha \\
\hline Percentage & $100 \%$ & $75,20 \%$ & $24,80 \%$ \\
\hline \multicolumn{4}{|c|}{ Source: Data of research result 2014}
\end{tabular}

The total area of mangrove forest in 2005 as a whole was still relatively good, however damages to mangrove forest have occurred since 2006 that were caused by the military coup in Timor-Leste that caused big waves of exodus of the people of Dili City that caused damages to the mangrove ecosystem in the region which could not be avoided, so that there was a need for a quick and appropriate handling of the damages to reduce or obstruct the destruction process of the mangrove forest to prevent the extension of the damages to the still existing mangrove potential. can be seen through a simple map the results of a 2005 study in Figure 2.

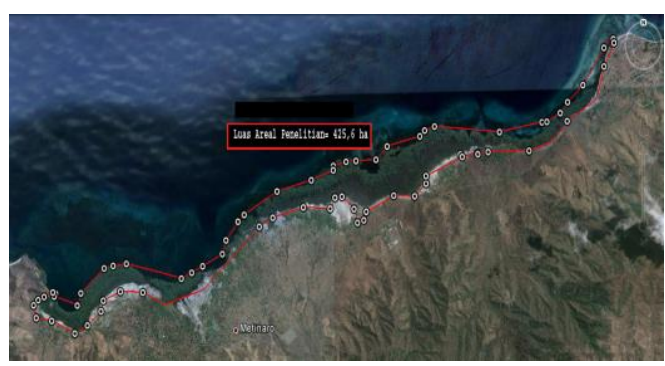

Fig. 2. Condition of mangrove forests in the coastal Metinaro in 2005

Based on this simple map authors believe that the total area of these is true, because in 2005 the newly independent East Timor more than three years so that the equipment and knowledge, especially the map is still quite minimal and almost non-existent.

\section{Mangroves and the community}

The mangrove forest ecosystem area in Metinaro District is very susceptible to damages caused by the community activities. This is because this area is not far from the residence of the community, even it is so close to the coastal community of Metinaro that the awareness of the local community is difficult to build since it is very easy to exploit the area.

Metinaro has abundant firewoods and woods for building materials that can give economic profit in the mangrove area, thus mangroves become the main attraction and so the destruction occurs, not only the destruction was done by the local community but also the destruction done by people who come from Dili. It is very easy to get firewoods and woods for building materials by using simple tools, they do not need a big capital to get them. The mangrove ecosystem has a high enough economic value so that the sustainable economic needs of the local community, especially the community that lives on 
the coast are determined by the existence of the mangrove forest.

Metinaro District has two villages and 13 habitation's that are close to the mangrove ecosystem. The total number of the people who live in the two villages is 4,631 . With this number of people and without building their awareness about the functions and the roles of the mangrove forest, the mangrove area is under a threat, both of being converted into an extension of ponds and being exploited for the existing mangrove potential.

The susceptibility of the mangrove forest to the destruction is closely related to the people's understanding of the functions and roles of the mangrove forest ecosystem. The results of interviews that the researcher did with the community of Metinaro showed that their attitude is easily changed because of economic factor. The change in their attitude is because they think mangroves are not important for them and they even think them as useless plants. This understanding caused them not to take care of the mangroves well, especially the ones with direct economic value, if in them there is a high enough economic value potential.

Metinaro community actually can assess the condition of the mangrove forest that exists in their area, they can see the condition. They can understand the existing mangrove ecosystem is becoming increasingly thinner by looking at the forest from the island toward the sea.

\section{Condition of mangrove ecosystem and factors that caused it}

Since 2006 up to the present time, the condition of the mangrove forest in Metinaro has increasingly become the subject of concern. This is caused more by the non-existing supervision from the related institution, thus the destruction occurred because of the economic need of the households which cause the loss of the forest functions as the protector of abrasion, as a place for the reproduction of various coastal biotas, as a place where they are looking for food and as a place that is visited by coastal birds. In addition to the loss of these functions, the thickness of the mangrove forest ecosystem has become less and less due to two factors: anthropogenic factor, this factor includes 1) the destruction of the mangrove forest by wild felling of the trees, and 2) the destruction of the forest due to the opening of new land and; natural factor, which includes 1) waves and storms, 2) the destruction due to the age of the plants, and 3) the destruction due to the domestic animals because of the dry season. The anthropogenic and natural factors have contributed very much to the thinning of the mangrove forest ecosystem in Metinaro beach and from the result of visual photographic analysis we can identify the causes of the destruction of Metinaro mangrove forest, which include:

1) Damage of the mangrove forest caused by human beings (anthropogenic)

a) Wild felling of trees

The result of the identification of the mangrove forest ecosystem shows that about 97,24 ha or $22,85 \%$ of the damage was anthropogenic, this can be explained in detail as follows:

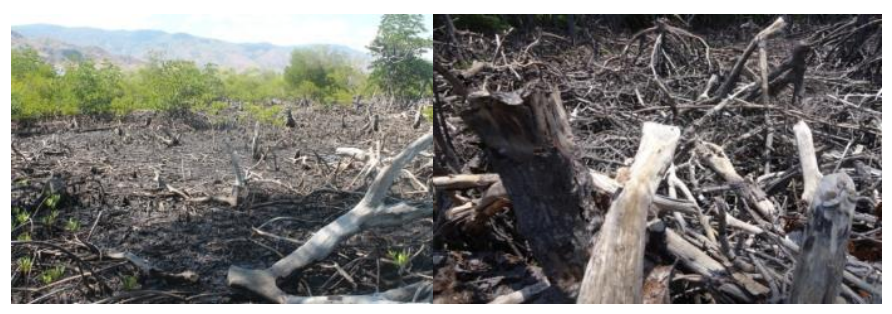

Fig. 3. Photograph of the result of research in 2014

Wild felling of trees is one of the main factors that cause damage to mangrove forest on Metinaro beach done by the people from the surrounding areas and those who came from the cities who fell trees illegally. The wild felling of trees that occur is usually done by the people to use them as firewoods and woods for building materials.

b) The opening off land (for shrimp, fish and crab ponds).

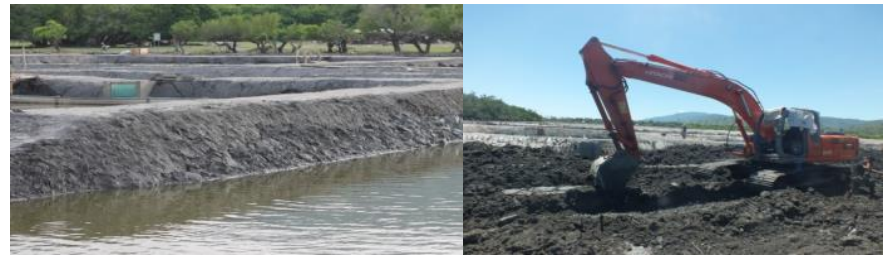

Fig. 4. Photograph of research result in 2014

The opening of land for ponds, both for nila fish, shrimps, and crabs. But now nila fish still dominates as one of the businesses done by businessmen together with the local people. The cutting of trees in the mangrove forest is done by the people who live around the forest to extend fishery areas and to get the wages to meet their daily needs, but the way they do this is illegal. The people do the cutting by damaging all mangrove forest without thinking of the impact in the future.

The action occurs in Metinaro beach because of 1) a growth in population, the increased number of the population will cause the increasingly less land for living and an increase in economic needs, so that they choose mangrove forest as the solution to the lack of housing and as the place to earn their living, and 2) illegal logging. The illegal logging on Metinaro coastal is not only done by the local people as to meet their economic demand and to increase their income to meet their family needs, but this activity is also done by business people who do the illegal logging outside the area that has been allocated, this often occurs in production forest land, protected forest, deep into the conservation zone and Conis Santana National Park.

The effort to prevent the people who fell trees who are not responsible for the mangrove forest ecosystem, the government or related offices needs to do their best to preserve and manage the mangrove forest ecosystem sustainably, so that some efforts need to be made such as 1) the effort to replant mangrove trees for those who did the destruction, 2) the 
prohibition to fell trees in the mangrove forest in all of its area for the sake of the common interest, 3) the effort to apply the system of selected felling of trees in felling mangrove trees if it is needed, 4) the effort to apply the felling and planting system in the activity of felling the mangrove trees in the mangrove forest, 5) the giving of a heavy sanction for those who violate the rule about the management of mangrove forest, and 6) a cooperation between the government or related offices with the stakeholders.

2) Damages to mangrove forest caused by nature

Damages to the mangrove forest that are caused by nature can be explained in detail as follows:

a) Waves and storms

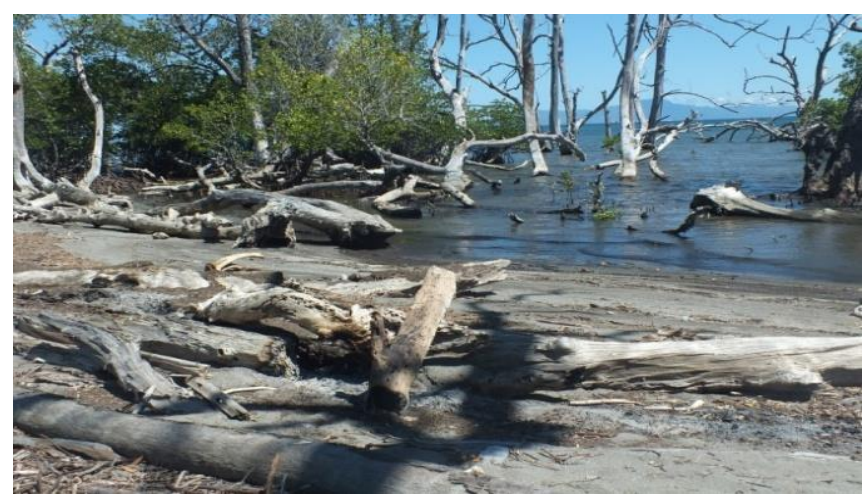

Fig. 5. Photograph of the result of research in 2014

The damage to the mangrove forest ecosystem occurs because of an event such as big waves in the east wind monsoon and the long dry season that can cause the accumulation of salt in plants (Khomsin, 2005) in Fadlan, (2010). Furthermore, big waves can cause the uprooting off young trees or the falling of trees, and cause land erosion where mangroves are growing. However, the occurrence of waves and storms are natural phenomena that cannot be evaded. These phenomena cause damages to the forest, especially the forests in Metinaro beach up to 6,36 ha=1,49\%.

b) Age of plants

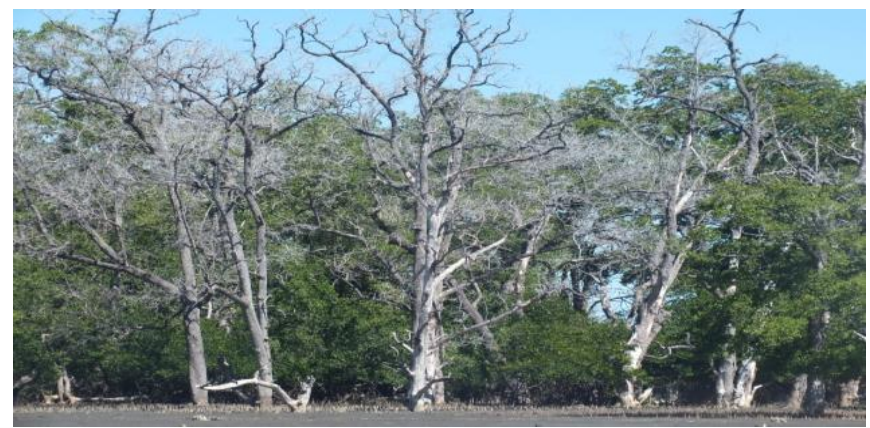

Fig. 6. Photograph of the result of research in 2014

Damage to the mangrove ecosystem can be caused by the age of the plant itself. If the plant has reached an older age, then it will die automatically without any other factors. In this study, there were some plots of damage to the mangrove ecosystem caused by the ages of the plants themselves.

c) Domestic animals

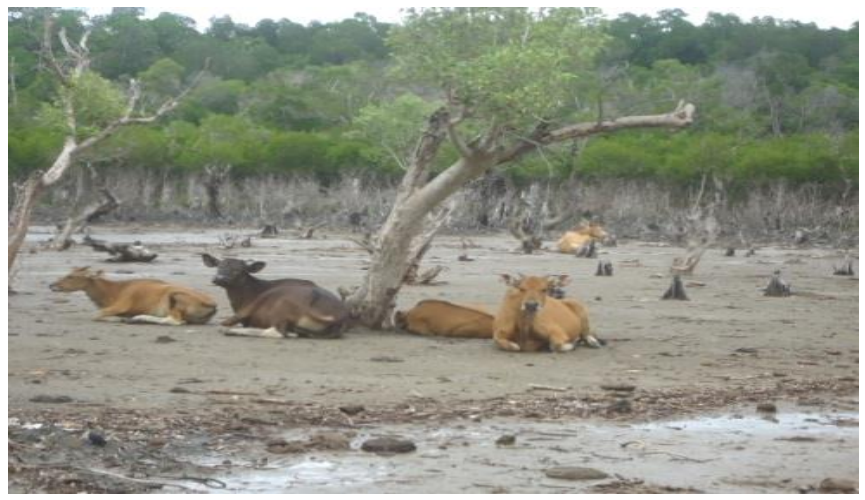

Fig. 7. Photograph of the result of research in 2014

An extended and continual dry season will trigger the occurrence off drought and burning of weeds around the location of research, thus the domestic animals will lack feed so that they will go to the beach especially for looking for feed, in this case, mangrove leaves and the seedlings of mangroves become their target. Khomsin (2005) in Fadlan, 2010) states that an extended drought will cause death to the mangrove vegetation and hinder their growth. However, such a phenomenon cannot be avoided, since this occurs because of God, the Almighty, will it to happen.

3) Potential of the damage to the mangrove forest ecosystem in Metinaro beach at present

On the whole, the potential of the mangrove forest ecosystem that is still existing can be seen in table 1 above. Thus, the potential of the mangrove that is still existing is around $320.06 \mathrm{ha}=75,20 \%$, while the mangrove that has been damaged is $105,54 \mathrm{ha}=24,80 \%$, thus the potential of damage to the mangrove forest in Metinaro falls into the medium category. It is expected that the government and related offices have the initiative to conserve and replant mangroves that have been increasingly thinner from year to year, in order the damage to the mangrove forest does not broaden. The damage to the mangrove forest ecosystem in Metinaro in detail has reached 105,54 ha, which is classified based on the impact of the damage, which includes: anthropogenic 99,18 ha, and nature 6.36 ha from the total area of the previous mangrove forest, i.e., 425,6 ha, while the area of research is 201,92 ha (not damaged) and 105,54 ha (damaged), so that the total area of research reaches 307,46 ha from 320,06 ha of the whole mangrove forest, while part of the mangrove forest ecosystem has been assigned by the local customary leader as sacred forests.

\section{CONCLUSIONS AND SUGGESTIONS}

The condition of the mangrove forest ecosystem in Metinaro region has been damaged, this is seen from the shrinking of the area and the thinning of the forest ecosystem, and we can conclude that: 
- The causes of the damage to the mangrove forest in Metinaro beach can be seen in two aspects, i.e., the anthropogenic aspect, i.e., a) damage to the mangrove forest that is caused by illegal logging (for firewoods, woods for building materials, and house and garden fences), and b) damage to the mangrove forest caused by waves and storms as the triggers of the natural destruction of the mangrove forest ecosystem, c) damage to the mangrove forest ecosystem caused by the age of the plants, and d) damage to the mangrove forest ecosystem caused by domestic animals as the consequence of drought or dry season.

- The anthropogenic cause becomes the main trigger of the mangrove forest ecosystem that is dominant in Metinaro beach which is up to 97,24 ha $(22,85 \%)$.

- The damage to the mangrove forest has caused the occurrence of beach abrasion, the increasingly thinning of the mangrove vegetation, and the decrease in biodiversity.

\section{ACKNOWLEDGMENT}

The completion of this work cannot be separated from the assistances, roles, and motivations from many people, thus on this occasion, the writer would like to express gratitude to Professor Dr. Ir. Mth. Sri Budiastuti, M.Si, as Promotor who has always given constructive guidance and direction both during the time of doing the research and the writing of this paper, Dr. Joko Sutrisno, MP, as Co-promotor 1 and Dr. Sunarto, MS, who has always given guidance and direction until the time when this paper was finished.

\section{REFERENCES}

[1] Alpha, 1976, Standard Methods for Water and Waste Water, American Public Health Association, Washington DC.

[2] Fadlan, Mohammad, 2011, Aktivitas Ekonomi Penduduk terhadap Kerusakan Ekosistem Hutan Mangrove di Kelurahan Bagan Deli Kecamatan Medan Belawan, Medan: Universitas Sumatera Utara.

[3] Haba, John., Muqtafa, Muhammad Khoirul., Siburian, Robert., Permadi, Sandi., Ulumuddin, Yaya Ihya, 2016, Konservasi Mangrove dan Kesejahteraan Masyarakat, Cetakan Pertama. Yayasan Pustaka Obor Indonesia, Jakarta.

[4] Noor YR, M Khazali dan INN Suryadiputra, 2006, Panduan Pengenalan Mangrove di Indonesia 2, 23-29. Wetlands International-Indonesia Program, Bogor.

[5] Onrizal, 2003, Hutan mangrove dan perlindungan pantai dari gelombang tsunami, Warta Konservasi Lahan Basah 11(3), 26-27.

[6] Sugiyono. 2010. Metode Penelitian Bisnis (Pendekatan Kuantitatif, Kualitatif dan R \& D). Penerbit Alfabeta Bandung.

[7] Suyadi. 2009. Kndisi Hutan Mangrove di Teluk Ambon: Prospek dan Tantangan [The Condition of Mangrove Forest in Ambon Bay: Prospect and Challenges] in Information Technology for Natural Resources Management Bogor Agricultural University-SEAMEO Biotrop. Berita Biologi 9 (5) - Aguslus 2009.

[8] Suyanto, Bagong dan Sutinah. 2005. Metode Penelitian Sosial Berbagai Alternatif Pendekatan, Edisi Ketiga, Penerbit Kencana Prenadamedia Group. Jakarta.

[9] Trainor, C.R., Coates, B. J., and Bishop, K.D. 2007. As Aves de Timor Leste. Birdlife International and Dove Publications. In Timor Leste. 